\title{
UPAYA MENURUNKAN RISIKO PRA SINDROM METABOLIK PADA REMAJA MELALUI PEMAHAMAN FAKTA NUTRISI DAN PELATIHAN SKRINING SEDERHANA
}

\author{
Gita Dwi Prasasty ${ }^{1 *}$, Dwi Handayani ${ }^{2}$, Dalilah $^{3}$, Chairil Anwar ${ }^{4}$, Desy Oktariana ${ }^{5}$, Evi \\ Luasiana $^{6}$, Nia Savitri Tamzil ${ }^{7}$ \\ Program Studi Pendidikan Dokter, Fakultas Kedokteran, Universitas Sriwijaya, Inderalaya \\ Jl. Mohammad Ali Palembang 35145 \\ Penulis Korespodensi : gdprasasty@gmail.com
}

\begin{abstract}
Abstrak
Pola penyakit di dunia modern ini telah mengalami perubahan. Adanya peningkatan higienitas individu dan lingkungan, standar kehidupan lebih baik, serta perkembangan antibiotik telah menggeser peringkat penyakit infeksi menjadi penyakit degeneratif seperti penyakit kardiovaskuler dan kanker, terutama pada daerah perkotaan. Penyakit kardiovaskuler, yang sekarang ini telah banyak ditemukan pada usia remaja, berhubungan dengan sindrom metabolik serta obesitas dan hipertensi sebagai komponennya. Pemahaman fakta nutrisi sangat membantu dalam menentukan asupan yang dibutuhkan sehubungan dengan mengurangi risiko terkena sindrom metabolik dan penyakit serius yang mengikutinya. Pengabdian masyarakat ini bertujuan untuk mendampingi siswa dalam memahami pentingnya fakta nutrisi dalam menurunkan faktor risiko sindrom metabolik serta pelatihan skrining sederhana. Kegiatan terbagi menjadi dua bagian, yaitu penyuluhan dan pemeriksaan, serta pelatihan. Penyuluhan dan pemeriksaan dilakukan oleh dokter melalui pemaparan materi dan diskusi mengenai pentingnya fakta nutrisi dan sindrom metabolik. Pelatihan dilakukan secara berpasangan dan dalam kelompok-kelompok kecil dengan panduan pendamping, yang selanjutnya dipraktikkan masing-masing peserta. Dengan adanya penyuluhan, pengetahuan siswa mengenai pra sindrom metabolik dan fakta nutrisi meningkat menjadi 90\% Sebesar 6,5\% siswa mengalami pra sindrom metabolik. Seluruh siswa (100\%) telah mampu melaksanakan skrining sederhana pengukuran lingkar perut, tekanan darah, IMT dan perhitungan kebutuhan kalori yang bermanfaat bagi siswa dan orang sekelilingnya.
\end{abstract}

Kata kunci: prasindrom metabolik, nutrisi, antropometri

\section{Pendahuluan}

Pola penyakit di dunia modern ini telah mengalami perubahan. Adanya peningkatan higienitas individu dan lingkungan, standar kehidupan lebih baik, serta perkembangan antibiotik telah menggeser peringkat penyakit infeksi menjadi penyakit degeneratif seperti penyakit kardiovaskuler dan kanker, terutama pada daerah perkotaan (Beck, 2011).

Sindrom metabolik sebagai salah satu penyebab penyakit serius seperti penyakit kardiovaskuler, pertama kali dikenalkan oleh Reaven tahun 1988 yang dikaitkannya dengan sindrom resistensi insulin. Kegagalan metabolik ini menimbulkan penyakit kardiovskuler juga menyebabkan berbagai penyakit serius lainnya berupa diabetes mellitus tipe 2 , sindrom ovarium polikistik dan sebagainya disertai komplikasi yang mengikutinya. Komponen sindrom metabolik

antara lain obesitas abdominal, dislipidemia, hiperglikemia, dan hipertensi. Sedangkan pra sindrom metabolik adalah terdapatnya satu sampai dua dari kriteria sindrom metabolik (Soegondo and Gustaviani, 2010).

Kejadian sindrom metabolik berkembang sehubungan dengan meningkatnya prevalensi obesitas pada penduduk Asia. Prevalensi obesitas, sebagai komponen sindrom metabolik, secara global telah meningkat tajam dalam beberapa dekade terakhir. Pada tahun 1990 sebesar 4,2\%, meningkat menjadi $6,7 \%$ di tahun 2010 dan diperkirakan akan mencapai 9,1\% di tahun 2020 . Obesitas yang dialami pada masa remaja akan memperbesar kemungkinan obesitas pada masa selanjutnya, terutama pada remaja dengan IMT lebih dari $40 \mathrm{~kg} / \mathrm{m} 2$. Berdasarkan data Riskesdas tahun 2007 dan 2013, telah terjadi peningkatan prevalensi gemuk pada usia remaja 16 - 18 tahun 
yaitu dari $1,4 \%$ menjadi $7,3 \%$. Penelitian di Jakarta mendapatkan prevalensi sindrom metabolik 34\% pada 50 remaja obes berusia 10-19 tahun. (Soegondo and Gustaviani, 2010; Pulungan et al., 2014).

Komponen lain yaitu dislipidemia, hipertensi dan resistensi insulin juga sudah ditemukan pada anak sehingga kemungkinan peningkatan kejadian penyakit kardiovaskuler di masa mendatang semakin besar. Oleh karena itu deteksi dini pra sindrom metabolik sangat diperlukan (Pulungan et al., 2014).

Kaitan diet dengan penyakit tertentu telah diakui dan dibuktikan melalui penelitian sebelumnya. Akan tetapi peranan diet sebagai penyebab atau faktor yang ikut menyebabkan penyakit belum dipahami dengan baik terutama oleh penduduk remaja karena memiliki usia muda dan kondisi sehat. Padahal hubungan ini sangat penting terutama pada penyakit penyebab utama kematian dan kesakitan di negara-negara maju. Penyebab paling penting adalah kolesterol serum yang sebagian besar berasal dari asupan lemak hewani yang tinggi sehingga menyebabkan kenaikan kadar lipid serum. Faktor diet lainnya antara lain adalah kandungan serat rendah, kandungan gula protein dan garam tinggi dalam makanan, air minum yang kurang mengandung mineral dan lemak tinggi (Beck, 2011).

Fakta nutrisi adalah label komponen gizi makanan yang terdapat pada suatu kemasan. Label ini berisi takaran penyajian, kalori dan nutrisi. Fakta nutrisi ini lebih tepat digunakan saat memiliki makanan karena dapat disesuaikan dengan kebutuhan tubuh. Namun sayangnya, individu terutama remaja memilih makanan hanya berdasarkan rasa, ketertarikan terhadap kemasan ataupun akibat persuasif pada media massa (Beck, 2011).

Kegiatan pengabdian masyarakat ini bertujuan untuk mendampingi siswa dalam memahami pentingnya membaca fakta nutrisi dalam memilih makanan serta melatih cara melakukan skrining sederhana pada diri sendiri dan lingkungan. Melalui kegiatan ini diharapkan dapat mendeteksi secara sederhana pra sindrom metabolik, memproteksi dan memperbaiki kesehatan diri melalui asupan makanan serta diharapkan menyebarkan ilmu kesehatan kepada lingkungan sekitar yang akhirnya membantu menurunkan risiko terkena pra sindrom metabolik dan penyakit kardiovaskuler di masa mendatang

\section{Metode Pelaksanaan}

Pemeriksaan kriteria pra sindrom metabolik dilakukan pada 50 siswa dan siswi kelas 8 di Sekolah Menengah Pertama Negeri 9 Palembang. Kegiatan dilakukan pada bulan November 2019. Kegiatan dimulai dengan diadakan pretest yang dilanjutkan penyuluhan. Penyuluhan dilakukan dengan pemaparan materi dan diskusi mengenai pra sindrom metabolic dan fakta nutrisi.

Agar ilmu yang disampaikan dapat lebih bermanfaat baik bagi siswa maupun orang sekitar, maka dilakukan pelatihan skrining pra sindrom metabolik sederhana. Kriteria pra sindrom metabolik yang digunakan adalah perhitungan lingkar perut dan tekanan darah. Standar yang digunakan berdasarkan Konsensus IDAI mengenai Diagnosis dan Tata Laksana Sindrom Metabolik pada remaja. IDAI menggunakan kriteria yang telah dimodifikasi sesuai dengan kriteria populasi anak Indonesia, antara lain lingkar perut (meteran) di atas persentil 80 (perempuan lebih dari $76 \mathrm{~cm}$ dan laki-laki lebih dari $77 \mathrm{~cm}$ ) serta tekanan darah (sphignomanometer dan stetoskop) di atas persentil 95 (perempuan 128/83mmHg dan laki-laki $130 / 83 \mathrm{mmHg}$ ). Selain itu, siswa juga dilatih membaca dengan baik fakta nutrisi pada label makanan kemasan yang kemudian disesuaikan dengan kebutuhan kalori perindividu perhari. Perhitungan Index Massa Tubuh (IMT) digunakan untuk mengetahui status gizi masing-masing. Teknik pelatihan yaitu peserta dibagi berpasangpasangan. Kemudan pendamping memeragakan cara melakukan pemeriksaan yang benar dan langsung diikuti oleh peserta. Pendamping membantu peserta apabila mengalami kesulitan atau kesalahan.

Kegiatan pelaksanaan pengabdian masyarakat diakhiri dengan evaluasi post-test, keaktifan peserta selama diskusi, tanya jawab setelah penyuluhan berlangsung, dan kemampuan peserta dalam melakukan deteksi pra sindrom metabolik.

\section{Hasil dan Pembahasan}

Kegiatan penyuluhan dibagi menjadi empat sesi, dengan sesi pertama berupa pengisian pre test sebanyak 10 soal. Kemudian dilanjutkan pemberian materi oleh ketua pengabdian masyarakat mengenai pra sindrom metabolik dan pemahaman fakta nutrisi untuk siswa remaja. Penyuluh juga memberikan contoh fakta nutrisi secara langsung pada makanan dan botol minuman 
yang dimiliki oleh siswa. Sesi berikutnya berupa diskusi. Ada sebanyak 6 orang siswa yang aktif bertanya mengenai pra sindrom metabolik dan pemahaman fakta nutrisi. Sesi terakhir berupa menjawab post test dan saran terhadap kegiatan penyuluhan yang telah berlangsung.

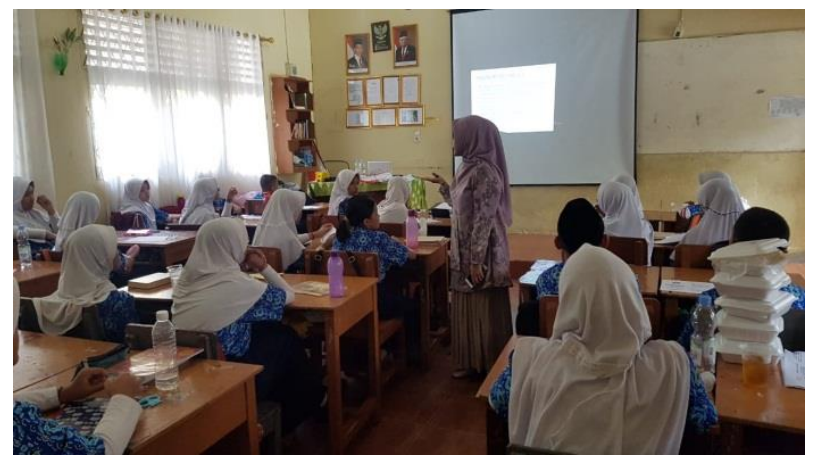

Gambar 1. Penyuluhan kepada siswa SMP N 9 Palembang

Pelatihan sekaligus pemeriksaan sederhana pra sindrom metabolik dilakukan terhadap semua siswa yang hadir. Kriteria yang digunakan antara lain : pemeriksaan IMT (tinggi badan dan berat badan), lingkap perut dan tekanan darah. Siswa dibagi menjadi 3 kelompok dimana tiap kelompok terdiri dari 15 orang yang didampingi oleh 1 orang anggota panitia. Tiap orang berpasangan dan bergantian dalam penggunaan alat. Anggota panitia mendampingi pemeriksaan sederhana ini sekaligus mencatat hasilnya di dalam form isian. Seluruh anggota tim berkoordinasi dan bertanggung jawab sesuai tugas masing-masing.

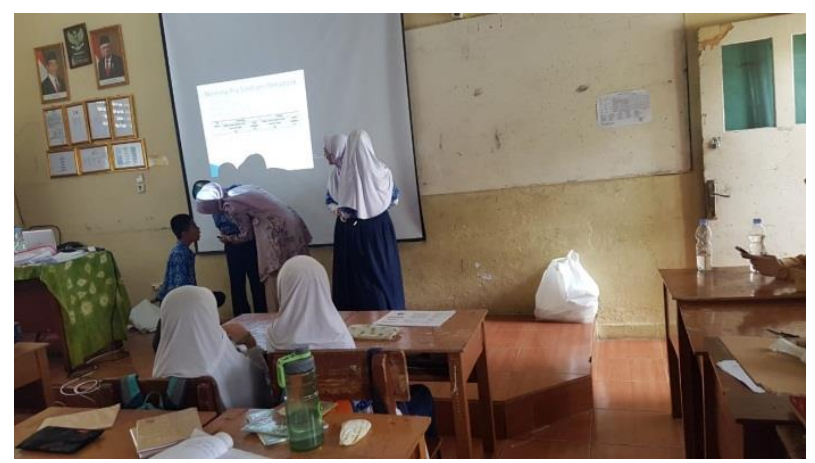

Gambar 2. Pelatihan skrining pra sindrom metabolik sederhana

Berdasarkan hasil pre test yang dilakukan terhadap 46 siswa, didapatkan bahwa sebagian besar $(70 \%)$ peserta sudah memiliki pengetahuan yang baik mengenai pra sindrom metabolik, kegemukan dan pentingnya memahami fakta nutrisi pada usia remaja. Tetapi tetap ada siswa yang berada pada rentang status gizi kurus $(34,7 \%)$ dan kegemukan $(10,8 \%)$. Sedangkan berdasarkan perhitungan lingkar perut, terdapat $35 \%$ yang mengalami obesitas sentral. Sehingga meskipun rentang status gizi siswa dalam batas normal tetapi masih ada yang mengalami obesitas sentral. Kriteria tekanan darah di atas normal dialami oleh $6,5 \%$ siswa dimana kesemua siswa tersebut memiliki lingkar perut yang tidak normal. Maka berdasarkan kriteri pra sindrom metabolik dapat disimpulkan bila angka kejadiannya sebesar $6,5 \%$ dari total 46 siswa.

Berdasarkan hasil diskusi dan tanya jawab, sebagian besar siswa memiliki kebiasaan untuk membeli camilan berupa minuman manis seperti minuman boba, teh manis botol ataupun olahan yang sering dijual di pusat perbelajaan. Begitupula dengan camilan makanan yang sebagian besar adalah gorengan.

Permasalahan yang dialami selama ini adalah siswa belum banyak yang mengetahui bahwa makanan camilan yang sering mereka konsumsi ternyata mengandung kalori dan kadar gula yang tinggi sehingga dengan pola makan tersebut berisiko menderita sindrom metabolik dimasa depan.

\section{Kesimpulan}

Sudah terdapat kejadian pra sindrom metabolik di SMP N 9 Palembang sebesar 6,5\% merupakan tantangan bagi tenaga kependidikan dan kesehatan untuk terus memantau dan mencegah pra sindrom metabolik pada remaja.

\section{Ucapan Terima Kasih}

Ucapan terima kasih terutama ditujukan kepada Universitas Sriwijaya yang telah memberikan dana hibah pengabdian masyarakat tahun 2019 .

\section{Daftar Pustaka}

Beck, M. E. (2011) 'Ilmu Gizi dan Diet', in Hartono, A. and Kristiani (eds) Ilmu Gizi dan Diet. Yogyakarta: Penerbit ANDI, p. 97.

Dieny, F. F., Widyastuti, N. and Fitranti, D. Y. (2017) 'Sindrom metabolik pada remaja obes: prevalensi dan hubungannya dengan kualitas diet', Jurnal Gizi Klinik Indonesia, 12(1), p. 1. doi: 10.22146/ijcn.22830.

Pulungan, A. et al. (2014) 'Diagnosis dan Tata laksana Sindrom Metabolik pada Anak dan Remaja', Ikatan Dokter Anak Indonesia, pp. 1-15. 
Soegondo, S. and Gustaviani, R. (2010) 'PAPDI SIND. Metabolik 2010.pdf', in Sudoyo, A. W. et al. (eds) Ilmu Penyakit Dalam. 3rd edn. Jakarta: Ilmu Penyakit Dalam FK UI, p. 1849. 